\title{
Kesesuaian Jenis Tanaman Pertanian dengan Kualitas Air Irigasi dari Beberapa Mata Air Karst di Kabupaten Tuban \\ Hari Siswoyo ${ }^{1 \star}$, Mohammad Bisri ${ }^{1)}$, Mohammad Taufik ${ }^{1)}$, Vanadani Pranantya ${ }^{1)}$ \\ 1) Jurusan Teknik Pengairan, Fakultas Teknik Universitas Brawijaya \\ *hari_siswoyo@ub.ac.id \\ DOI: https://doi.org/10.21107/rekayasa.v13i3.7869
}

\begin{abstract}
This research was conducted with the aim to describe the types of non-paddy agricultural crops that can be cultivated on agricultural land with irrigation water sources from karst springs. This research was conducted at 10 locations of karst springs that are used to irrigate agricultural land in Tuban Regency. Determination of alternative of types of nonrice agricultural crops is done by integrating the irrigation water quality index model, criteria of relative tolerance of crops to salt, and criteria of non-rice agricultural crops that have high economic value. Irrigation water quality index values from karst springs at the study location ranged from 73.99 to 76.23, which is in the range of 70-85 with a low water use restriction. Based on the irrigation water quality index values it can be recommended that water supply for irrigation from karst springs is not carried out on salt sensitive crops. The non-paddy agricultural crop types that can be recommended to be planted in the study location are corn (Zea mays), soybeans (Glycine max), peanuts (Arachis hypogaea), sweet potatoes (Ipomoea batatas), tomatoes (Lycopersicon lycopersicum), eggplants (Solanum melongena), cucumbers (Cucumis sativus), spinach (Spinacia oleracea), melons (Cucumis melo), and watermelons (Citrullus lanatus).
\end{abstract}

Keywords: agricultural crops, groundwater, irrigation, karst springs, water quality

\section{PENDAHULUAN}

Wilayah Kabupaten Tuban berada dalam rangkaian Perbukitan Lipatan Rembang yang memiliki bentang lahan karst (kategori karst muda) yang tersusun atas batuan gamping dan terumbu muda. Wilayah tersebut merupakan perbukitan karst dengan karakteristik ketinggian bervariasi antara $50-400 \mathrm{~m}$ di atas permukaan laut, yang dicirikan oleh perbukitan kasar dan terjal, dolina, goa-goa, dan sungai bawah tanah (Zaenuri \& Haryono, 2015). Keberadaan perbukitan karst yang mendominasi wilayah Kabupaten Tuban menjadikan wilayah tersebut banyak memiliki mata air karst.

Pemanfaatan potensi mata air karst di Kabupaten Tuban diantaranya adalah digunakan sebagai sumber air irigasi. Potensi mata air karst sebagai sumber air irigasi bagi lahan pertanian sudah seharusnya dimanfaatkan seefektif dan seefisien mungkin agar dapat memberikan manfaat bagi petani khususnya pendapatan yang

\section{Article History:}

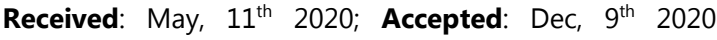
Rekayasa ISSN: 2502-5325 has been Accredited by Ristekdikti (Arjuna) Decree: No. 23/E/KPT/2019 August 8th, 2019 effective until 2023 layak dari hasil produksi pertanian. Pendapatan yang layak akan dapat diperoleh petani jika dalam penentuan jenis tanaman pertanian yang diusahakan, khususnya untuk tanaman non padi, dipilih tanaman bernilai ekonomi tinggi. Kriteria tanaman non padi bernilai ekonomi tinggi antara lain (Haryono et al., 2009): memberikan keuntungan lebih besar daripada tanaman padi, cara bercocok tanam tanaman tersebut telah dikuasai petani setempat, dan hasil pertanian tersebut dapat diserap oleh pasar.

Penentuan jenis tanaman pertanian yang diusahakan pada lahan pertanian harus memperhatikan kesesuaian tanaman tersebut dengan sejumlah faktor antara lain kondisi iklim dan kondisi lahan. Kesesuaian antara jenis tanaman pertanian (komoditas pertanian) dengan faktor-faktor tersebut telah diungkap dalam sejumlah penelitian terdahulu, antara lain: kesesuaian komoditas pertanian dengan iklim

\section{Cite this as:}

Siswoyo, H., Bisri, M., Taufik, M \& Pranantya, V. (2020). Kesesuaian Jenis Tanaman Pertanian dengan Kualitas Air Irigasi dari Beberapa Mata Air Karst di Kabupaten Tuban. Rekayasa, 13 (3), 246-253. doi:

https://doi.org/10.21107/rekayasa.v13i3.7869

(c) 2020 Hari Siswoyo, Mohammad Bisri, Mohammad Taufik, Vanadani Pranantya 
(Las, 1992), kesesuaian komoditas pertanian dengan kualitas lahan (Djaenudin et al., 1997), kesesuaian komoditas pertanian dengan kondisi pedo-agroklimat (Djaenudin et al., 2002), dan kesesuaian komoditas pertanian berdasarkan zona agroekologi (Saidi \& Suryani, 2019). Saat ini telah berkembang penelitian kesesuaian jenis tanaman pertanian dengan kualitas air irigasi yang digunakan untuk mengairi lahan pertanian (Siswoyo et al., 2016; Siswoyo et al., 2020) berdasarkan pendekatan nilai indeks kualitas air irigasi (Irrigation Water Quality Index) yang disingkat dengan IWQI (Meireles et al., 2010), kriteria toleransi relatif tanaman terhadap garam (Ayers \& Westcot, 1994), dan kriteria tanaman pertanian non padi bernilai ekonomi tinggi (Haryono et al., 2009).

Penelitian kesesuaian jenis tanaman pertanian dengan kualitas air irigasi yang digunakan untuk mengairi lahan pertanian, sejauh ini dilakukan pada lahan irigasi air tanah yang memanfaatkan potensi air tanah dalam (akufer terkekang) di daerah cekungan air tanah (Siswoyo et al., 2016; Siswoyo et al., 2020). Penelitian sejenis belum dilakukan pada lahan pertanian dengan sumber air irigasi dari mata air karst. Metode penentuan alternatif jenis tanaman pertanian bernilai ekonomi tinggi yang telah disusun dan digunakan di dalam penelitian sebelumnya (Siswoyo et al., 2016; Siswoyo et al., 2020) selanjutnya akan digunakan sebagai alat analisis untuk menentukan jenis tanaman pertanian non padi bernilai ekonomi tinggi yang dapat diusahakan pada lahan pertanian dengan sumber air irigasi dari mata air karst.
Penelitian ini dilakukan dengan tujuan khusus untuk mendeskripsikan jenis tanaman pertanian non padi yang memiliki nilai ekonomi tinggi dan dapat dibudidayakan pada lahan pertanian dengan sumber air irigasi yang berasal dari mata air karst di wilayah Kabupaten Tuban berdasarkan kualitas air irigasi tersebut. Tujuan umum dilakukannya penelitian ini adalah untuk mengeneralisasi penggunaan metode yang telah disusun dan digunakan dalam penelitian sebelumnya (Siswoyo et al., 2016; Siswoyo et al., 2020) di daerah dengan kondisi yang berbeda baik lahan pertanian maupun sumber air irigasinya. Hasil penelitian ini diharapkan dapat memberikan manfaat secara praktis bagi petani di lokasi penelitian yaitu sebagai bahan pertimbangan dalam menentukan alternatif jenis tanaman pertanian non padi bernilai ekonomi tinggi yang dapat diusahakan pada lahan pertaniannya.

\section{METODE PENELITIAN}

\section{Lokasi dan Waktu Pelaksanaan Penelitian}

Penelitian ini dilakukan di wilayah Kabupaten Tuban Provinsi Jawa Timur dengan obyek penelitian mata air karst yang potensi sumber daya airnya digunakan untuk irigasi. Kegiatan pengambilan contoh penelitian dilakukan pada bulan Juli 2019, pada saat musim kemarau dengan tujuan untuk mencegah atau setidaknya meminimalkan kemungkinan terjadinya pencampuran air yang keluar dari mata air dengan air hujan.

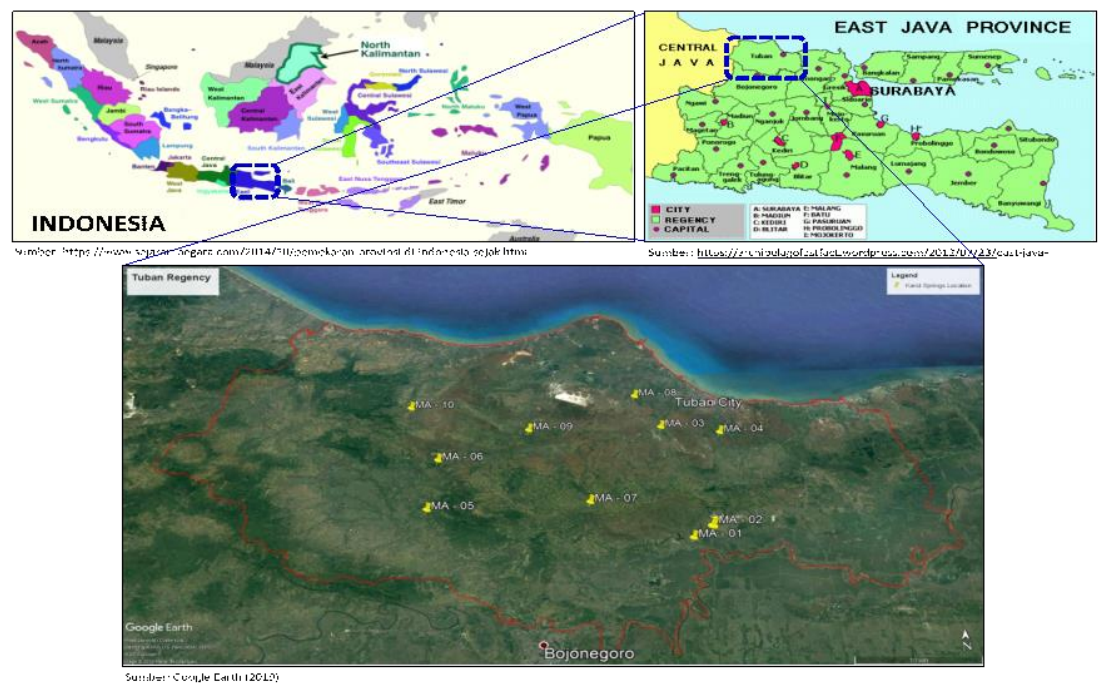

Gambar 1. Lokasi Penelitian 
Nama-nama mata air karst yang diteliti beserta lokasinya adalah sebagai berikut: Mata Air Ngerong (MA-01) di Kecamatan Rengel, Mata Air Beron (MA-02) di Kecamatan Rengel, Mata Air Jadi (MA-03) di Kecamatan Semanding, Mata Air Bektiharjo (MA-04) di Kecamatan Semanding, Mata Air Mejiret (MA-05) di Kecamatan Singgahan, Mata Air Kerawak (MA-06) di Kecamatan Montong, Mata Air Lanang (MA-07) di Kecamatan Montong, Mata Air Srunggo (MA08) di Kecamatan Merakurak, Mata Air Ngajaran (MA-09) di Kecamatan Kerek, dan Mata Air Bangkok (MA-10) di Kecamatan Kerek (Siswoyo et al., 2019). Peta lokasi penelitian ditunjukkan dalam Gambar 1.

\section{Alat dan Bahan}

Peralatan yang digunakan dalam penelitian ini meliputi: konduktimeter model $\mu$ Siemen digital conductivity tester, botol dari bahan poli etilen dengan volume 1 liter, dan kotak pendingin yang diisi dengan es gel balok. Bahan penelitian ini adalah contoh air yang diambil dari 10 lokasi mata air karst di wilayah Kabupaten Tuban yang dimanfaatkan untuk irigasi seperti dideskripsikan di atas.

\section{Metode Analisis}

Parameter fisiko-kimia tiap contoh air dari mata air yang diamati dan digunakan sebagai nilai masukan untuk perhitungan model indeks kualitas air irigasi (model IWQI) meliputi daya hantar listrik (DHL) dan kandungan ion-ion terlarut dalam air $\left(\mathrm{Na}^{+}, \mathrm{Ca}^{2+}, \mathrm{Mg}^{2+}, \mathrm{HCO}_{3}{ }^{-}\right.$, dan $\mathrm{Cl}^{-}$ ). Nilai DHL diukur secara langsung di lapangan dengan menggunakan alat konduktimeter model $\mu$ Siemen digital conductivity tester, kandungan ion-ion terlarut dalam contoh air seperti $\mathrm{Na}^{+}$, $\mathrm{Ca}^{2+}, \mathrm{Mg}^{2+}$, dan $\mathrm{Cl}^{-}$dianalisis di Laboratorium Kimia Fakultas MIPA Universitas Negeri Malang, sedangkan kandungan anion $\mathrm{HCO}_{3}{ }^{-}$dalam contoh air dianalisis di Laboratorium Tanah dan Air Tanah Fakultas Teknik Universitas Brawijaya.
Hasil analisis parameter fisiko-kimia terhadap contoh penelitian telah dideskripsikan pada bagian publikasi sebelumnya (Siswoyo et al., 2019).

Perhitungan nilai indeks kualitas air untuk irigasi berdasarkan model IWQI dilakukan dengan tahapan sebagai berikut:

1. Perhitungan nilai rasio serapan natrium (SAR) terkoreksi/yang disesuaikan (SAR ${ }^{\circ}$ atau $\mathrm{SAR}_{\mathrm{adj}}$ ) berdasarkan persamaan (Lesch \& Suarez, 2009):

$$
\mathrm{SAR}_{\mathrm{adj}}=\frac{\mathrm{Na}^{+}}{\sqrt{\frac{\left(\mathrm{Ca}_{\mathrm{eq}}+\mathrm{Mg}^{2+}\right)}{2}}}
$$

Keterangan:

$\mathrm{Ca}_{\text {eq }}=$ Konsentrasi $\mathrm{Ca}^{2+}$ yang diseimbangkan (Meq/Liter)

SAR $_{\text {adj }}=$ nilai SAR yang disesuaikan

2. Perhitungan nilai kualitas air terukur $\left(q_{i}\right)$ berdasarkan persamaan (Meireles et al., 2010)

$\mathrm{q}_{\mathrm{i}}=\mathrm{q}_{\mathrm{i} \max }-\left[\frac{\left(\mathrm{x}_{\mathrm{ij}}-\mathrm{x}_{\mathrm{inf}}\right) \cdot \mathrm{q}_{\mathrm{i}_{\mathrm{amp}}}}{\mathrm{x}_{\mathrm{amp}}}\right]$

Keterangan:

Q $=$ Nilai Kualitas Air Terukur

$\mathrm{Q}_{\mathrm{i} \text { Max }}=$ Nilai Maksimum Qi Untuk Kelas

$\mathrm{X}_{\mathrm{ij}} \quad=$ Nilai Parameter Yang Diamati

$X_{\text {inf }}=$ Nilai Yang Sesuai Dengan Batas

Bawah Kelas Dari Parameter

$\mathrm{Q}_{\mathrm{i} A \mathrm{mp}}=$ Jangkauan Kelas

$\mathrm{X}_{\mathrm{amp}}=$ Jangkauan Kelas Dari Parameter

Nilai $q_{i}$ dihitung untuk tiap parameter berdasarkan nilai-nilai batas parameter seperti yang ditunjukkan dalam Tabel 1 .

3. Perhitungan nilai IWQI berdasarkan persamaan (Meireles et al., 2010):

$\mathrm{IWQI}=\sum_{\mathrm{i}=1}^{\mathrm{n}} \mathrm{q}_{\mathrm{i}} \cdot \mathrm{w}_{\mathrm{i}}$

Tabel 1. Nilai Batas Parameter untuk Perhitungan $\mathrm{q}_{i}$

\begin{tabular}{clllll}
\hline $\mathbf{q}_{\mathbf{i}}$ & \multicolumn{1}{c}{$\begin{array}{c}\mathbf{D H L} \\
(\boldsymbol{\mu} \mathbf{S} / \mathbf{c m})\end{array}$} & $\begin{array}{c}\mathbf{S A R}_{\mathbf{a d j}} \\
(\mathbf{m e q} / \mathbf{l i t e r})^{\mathbf{0} \mathbf{5}}\end{array}$ & $\begin{array}{c}\mathbf{N a}^{+} \\
(\mathbf{m e q} / \mathbf{l})\end{array}$ & $\begin{array}{c}\mathbf{C l}^{-} \\
(\mathbf{m e q} / \mathbf{l})\end{array}$ & $\begin{array}{c}\mathbf{H C O}^{-} \\
(\mathbf{m e q} / \mathbf{l})\end{array}$ \\
\hline $85-100$ & $200 \leq \mathrm{DHL}<750$ & $\mathrm{SAR}<3$ & $2 \leq \mathrm{Na}^{+}<3$ & $\mathrm{Cl}^{-}<4$ & $1 \leq \mathrm{HCO}_{3}^{-}<1,5$ \\
$60-85$ & $750 \leq \mathrm{DHL}<1.500$ & $3 \leq \mathrm{SAR}<6$ & $3 \leq \mathrm{Na}^{+}<6$ & $4 \leq \mathrm{Cl}^{-}<7$ & $1,5 \leq \mathrm{HCO}_{3}^{-}<4,5$ \\
$35-60$ & $1.500 \leq \mathrm{DHL}<3.000$ & $6 \leq \mathrm{SAR}<12$ & $6 \leq \mathrm{Na}^{+}<9$ & $7 \leq \mathrm{Cl}^{-}<10$ & $4,5 \leq \mathrm{HCO}_{3}^{-}<8,5$ \\
$0-35$ & $\mathrm{DHL}<200$ atau & $\mathrm{SAR} \geq 12$ & $\mathrm{Na}^{+}<2$ atau & $\mathrm{Cl}^{-} \geq 10$ & $\mathrm{HCO}_{3}^{-}<1$ atau \\
& $\mathrm{DHL} \geq 3.000$ & & $\mathrm{Na}^{+} \geq 9$ & & $\mathrm{HCO}_{3}^{-} \geq 8,5$ \\
\hline
\end{tabular}

Sumber: Ayers \& Westcot (1994), Khalaf \& Hassan (2013), Al-Mussawi (2014), Omran et al. (2014) 
Keterangan:

IWQI = Indeks Kualitas Air Irigasi (Angka Tak Berdimensi Antara 0-100)

$\mathrm{Q}_{\mathrm{i}} \quad=$ Nilai Kualitas Air Dari Parameter KeI, Besarnya Antara 0-100, Merupakan Fungsi Dari Konsentrasi Atau Nilai Hasil Pengukuran.

$\mathrm{w}_{\mathrm{i}}$ = faktor pembobot dari parameter ke-i, merupakan fungsi tingkat pengaruh relatif dari nilai kualitas air.

Besarnya faktor pembobot tiap parameter, berturut-turut adalah sebagai berikut : $\mathrm{W}_{\mathrm{DHL}}=$ 0,$211 ; \mathrm{w}_{\text {SARadj }}=0,189, \mathrm{w}_{\mathrm{Na}}=0,204 ; \mathrm{w}_{\mathrm{Cl}}=0,194$, dan $\mathrm{W}_{\mathrm{HCO}}=0,202$. Nilai IWQI berdasarkan hasil perhitungan tersebut dapat diinterpretasikan dalam 5 kategori, yaitu: nilai 85-100 (tidak ada batasan penggunaan air) dimana air irigasi tidak memiliki resiko toksisitas bagi sebagian besar tanaman, nilai 70-85 (batasan penggunaan air rendah) dimana air irigasi perlu dihindari penggunaannya pada tanaman-tanaman yang sensitif terhadap garam, nilai 55-70 (batasan penggunaan air sedang) dimana air irigasi dapat diberikan terhadap tanaman dengan toleransi sedang terhadap garam, nilai 40-55 (batasan penggunaan air tinggi) dimana air irigasi dapat digunakan untuk tanaman dengan toleransi sedang hingga tinggi terhadap garam dengan tindakan khusus pengendalian salinitas, dan nilai $<40$ (batasan penggunaan air parah) dimana air irigasi hanya dapat diberikan untuk tanaman dengan toleransi yang tinggi terhadap garam.

Penentuan kesesuaian jenis tanaman pertanian non padi yang memiliki nilai ekonomi tinggi dan dapat dibudidayakan pada lahan pertanian di lokasi penelitian dengan kualitas air irigasinya dilakukan berdasarkan tahapan (Siswoyo et al., 2016; Siswoyo et al., 2020):

1. Penyesuaian kategori tamanan yang direkomendasikan berdasarkan hasil perhitungan nilai IWQI dengan kriteria toleransi relatif tanaman-tanaman pertanian terhadap garam. Kriteria toleransi relatif tanaman-tanaman pertanian terhadap garam meliputi: tanaman toleran terhadap garam, tanaman cukup toleran terhadap garam, tanaman cukup sensitif terhadap garam, dan tanaman sensitif terhadap garam (Ayers \& Westcot, 1994).

2. Penyesuaian kategori tanaman berdasarkan kriteria toleransinya tanaman terhadap garam dengan jenis tanaman pertanian non padi yang termasuk dalam kategori tanaman bernilai ekonomi tinggi (high value crops) yang direkomendasikan di dalam Kriteria Pengembangan dan Pengelolaan Irigasi Air Tanah (Haryono et al., 2009).

3. Penyesuaian kategori tanaman pertanian non padi bernilai ekonomi tinggi dengan tanaman-tanaman yang cara bercocok tanamnya sudah umum dikuasai para petani dan telah umum dibudidayakan di wilayah setempat, dalam hal ini di Kabupaten Tuban (Badan Pusat Statistik Kabupaten Tuban, 2018).

\section{HASIL DAN PEMBAHASAN}

Berdasarkan nilai parameter-parameter terukur seperti $\mathrm{DHL}$ dan kandungan ion-ion terlarut dalam contoh air $\mathrm{Na}^{+}, \mathrm{Ca}^{2+}, \mathrm{Mg}^{2+}, \mathrm{HCO}_{3}{ }^{-}$ , $\mathrm{Cl}^{-}$) yang telah dideskripsikan dalam publikasi sebelumnya (Siswoyo et al., 2019), dapat dihitung nilai SAR adj dan nilai IWQI untuk tiap contoh air irigasi dari mata air karst di lokasi penelitian. Hasil perhitungan nilai SARadj ditunjukkan dalam Tabel 2.

Nilai $S A R_{a d j}$ yang diperoleh berdasarkan perhitungan dalam Tabel 2 di atas lebih rendah dibandingkan hasil perhitungan nilai SAR (Siswoyo et al., 2019). Secara umum, nilai SAR merepresentasikan indeks bahaya natrium (alkalinitas) air yang digunakan untuk irigasi. Namun demikian, untuk air dengan konsentrasi $\mathrm{Ca}^{2+}$ dan/atau $\mathrm{HCO}_{3}^{-}$yang cukup besar, ion-ion tersebut akan mengendap ke tanah sebagai $\mathrm{CaCO}_{3}$. Untuk air dengan kandungan $\mathrm{Ca}^{2+}$ dan/atau $\mathrm{HCO}_{3}{ }^{-}$tinggi (terutama air tanah dengan kadar $\mathrm{CO}_{2}$ tinggi), direkomendasikan penggunaan formula $S A R_{\text {adj }}$ (Lesch \& Suarez, 2009). Rendahnnya nilai SAR berpengaruh pada rendahnya adsorpsi natrium oleh tanah, sehingga struktur tanah tetap dapat terjaga dan tanaman dapat tumbuh secara optimal (Hidayat et al., 2016). Berdasarkan nilai $S A R_{a d j}$ hasil perhitungan di atas dan nilai parameter model lainnya $\left(\mathrm{Na}^{+}, \mathrm{HCO}_{3}{ }^{-}, \mathrm{Cl}^{-}\right.$, dan $\mathrm{DHL}$ ) (Siswoyo et al., 2019) diperoleh hasil perhitungan nilai IWQI dan penentuan batasan penggunaan air untuk irigasi seperti ditunjukkan dalam Tabel 3. 
Tabel 2. Perhitungan Nilai SAR adj tiap Mata Air Karst di Lokasi Penelitian

\begin{tabular}{|c|c|c|c|c|c|c|c|c|c|c|}
\hline \multirow[t]{2}{*}{ No } & \multirow{2}{*}{$\begin{array}{l}\text { Kode } \\
\text { Contoh }\end{array}$} & \multicolumn{4}{|c|}{ Kandungan ion terlarut (meq/liter) } & \multirow[t]{2}{*}{ SC } & \multirow[t]{2}{*}{ IS } & \multirow[t]{2}{*}{$\log X$} & \multirow{2}{*}{$\begin{array}{c}\mathrm{Ca}_{\mathrm{eq}} \\
\text { (meq/liter) }\end{array}$} & \multirow{2}{*}{$\begin{array}{c}\text { SAR }_{\text {adj }} \\
\text { (meq/liter) }\end{array}$} \\
\hline & & $\mathrm{Na}^{+}$ & $\mathrm{Ca}^{2+}$ & $\mathbf{M g}^{2+}$ & $\mathrm{HCO}_{3}^{-}$ & & & & & \\
\hline 1 & MA-01 & 0,01 & 2,38 & 1,64 & 5,60 & 4,04 & 0,0060 & 0,79 & 1,10 & 0,01 \\
\hline 2 & MA-02 & 0,01 & 1,93 & 2,47 & 6,00 & 4,41 & 0,0065 & 0,71 & 0,92 & 0,01 \\
\hline 3 & MA-03 & 0,01 & 3,07 & 0,15 & 4,80 & 3,23 & 0,0049 & 0,90 & 1,43 & 0,01 \\
\hline 4 & MA-04 & 0,03 & 3,07 & 0,54 & 6,00 & 3,64 & 0,0054 & 0,84 & 1,24 & 0,03 \\
\hline 5 & MA-05 & 0,02 & 3,19 & 0,49 & 5,20 & 3,70 & 0,0055 & 0,90 & 1,40 & 0,02 \\
\hline 6 & MA-06 & 0,01 & 3,23 & 1,45 & 6,40 & 4,69 & 0,0069 & 0,85 & 1,25 & 0,01 \\
\hline 7 & MA-07 & 0,02 & 1,93 & 2,85 & 5,60 & 4,80 & 0,0070 & 0,74 & 0,97 & 0,01 \\
\hline 8 & MA-08 & 0,02 & 3,24 & 0,45 & 6,00 & 3,71 & 0,0055 & 0,86 & 1,28 & 0,02 \\
\hline 9 & MA-09 & 0,01 & 3,42 & 0,51 & 6,00 & 3,95 & 0,0059 & 0,88 & 1,34 & 0,01 \\
\hline 10 & MA-10 & 0,01 & 2,36 & 2,14 & 6,00 & 4,52 & 0,0066 & 0,77 & 1,06 & 0,01 \\
\hline
\end{tabular}

Tabel 3. Hasil Perhitungan Nilai IWQI dan Penentuan Batasan Penggunaan Air Irigasi

\begin{tabular}{cccc}
\hline No & Kode Contoh & IWQI & Batasan Penggunaan Air \\
\hline 1 & MA-01 & 75,33 & Rendah \\
2 & MA-02 & 74,69 & Rendah \\
3 & MA-03 & 76,23 & Rendah \\
4 & MA-04 & 74,43 & Rendah \\
5 & MA-05 & 75,11 & Rendah \\
6 & MA-06 & 73,99 & Rendah \\
7 & MA-07 & 74,76 & Rendah \\
8 & MA-08 & 74,42 & Rendah \\
9 & MA-09 & 74,22 & Rendah \\
10 & MA-10 & 74,52 & \\
\hline
\end{tabular}

Berdasarkan Tabel 3 di atas dapat dinyatakan bahwa nilai IWQI air dari mata air karst di lokasi penelitian berkisar antara 73,99 sampai dengan 76,23 , semuanya berada dalam rentang nilai $70-$ 85 dan berada dalam kategori batasan penggunaan air rendah. Kualitas air irigasi dalam kategori tersebut dapat direkomendasikan untuk digunakan sebagai air irigasi pada tanah dengan tekstur ringan atau permeabilitas sedang, dan dianjurkan untuk dilakukan pencucian garam. Sodisitas tanah dapat terjadi pada tanah dengan tekstur berat, dan dianjurkan untuk menghindari penggunaannya pada tanah dengan kandungan liat tinggi. Dalam kaitannya dengan jenis tanaman yang diusahakan pada lahan pertanian, penggunaan air irigasi dalam kategori ini harus dihindarkan terhadap resiko pada tanaman yang sensitif terhadap garam (Meireles et al., 2010).

Nilai indeks kualitas air dari mata air karst yang diperoleh dalam penelitian ini lebih memiliki keseragaman rentang nilai dan katagori batasan penggunaannya dibandingkan dengan penelitian terdahulu yang dilakukan berdasarkan contoh penelitian air tanah dalam pada akuifer terkekang yang diambil dari sumur produksi baik di Kabupaten Jombang (Siswoyo et al., 2016) maupun di Kabupaten Mojokerto (Siswoyo et al.,
2020). Air tanah dalam yang diteliti berdasarkan contoh penelitian sumur produksi di wilayah Kabupaten Jombang teridentifikasi berada dalam 3 kategori batasan penggunaan air yaitu batasan penggunaan air rendah sebanyak $48 \%$ dari contoh penelitian, batasan penggunaan air sedang sebanyak $48 \%$ dari contoh penelitian, dan tanpa batasan penggunaan air sebanyak $4 \%$ dari contoh penelitian. Sementara itu, berdasarkan penelitian di Kabupaten Mojokerto yang juga dilakukan terhadap air tanah dalam dari sumur produksi, teridentifikasi 2 kategori batasan penggunaan air yaitu batasan penggunaan air rendah sebanyak 90\% dari contoh penelitian dan batasan penggunaan air sedang sebanyak $10 \%$ dari contoh penelitian.

Nilai indeks kualitas dan batasan penggunaan air tanah dalam pada akuifer terkekang sebagai sumber air irigasi lebih bervariasi dibandingkan air dari mata air karst. Namun demikian, hal ini tidak terkait dengan kedalaman air tanah (sumur), asal terdapatnya air tanah, ataupun jenis akuifer. Kualitas air tanah termasuk dalam hal ini air dari mata air lebih dipengaruhi oleh komposisi zat terlarut atau unsur kimia yang terkandung di dalamnya, yang dikendalikan oleh sejumlah faktor (Siswoyo et al., 2020). Salah satu 
faktor pengendali komposisi zat terlarut dalam air tanah yang menyebabkan keseragaman kualitas air dari mata air karst yang diteliti adalah kondisi daerah dimana air dan batuan berhubungan. Lokasi pengambilan contoh dalam penelitian ini seluruhnya adalah daerah karst yang tersusun atas batuan karbonat yang kaya akan mineral kalsit dan mineral dolomit dimana air tanahnya termasuk juga mata air memiliki konsentrasi kation $\mathrm{Ca}^{2+}$, kation $\mathrm{Mg}^{2+}$, dan anion $\mathrm{HCO}_{3}{ }^{-}$lebih tinggi daripada ion-ion lainnya (Siswoyo et al., 2019).

Berdasarkan sejumlah penelitian yang telah dilakukan di wilayah Provinsi Jawa Timur baik terhadap air tanah dalam di Kabupten Jombang (Siswoyo et al., 2016), air tanah dalam di Kabupten Mojokerto (Siswoyo et al., 2020), maupun air yang berasal dari mata air karst di Kabupaten Tuban, tidak ditemukan kategori air irigasi dengan batasan penggunaan tinggi (nilai IWQI 40-55) ataupun batasan penggunaan parah (nilai IWQI < 40). Air tanah dengan batasan penggunaan air tinggi dan parah untuk irigasi, sejauh ini ditemukan dalam sejumlah penelitian di daerah semi kering hingga kering (Khalaf \& Hassan, 2013; Al-Mussawi, 2014; Omran et al., 2014; Abdulhady et al., 2018). Untuk itu, perlu dilakukan penelitian lanjutan untuk mengeneralisasi penggunaan metode atau prosedur yang telah disusun dan digunakan dalam penelitian ini dengan menggunakan contoh penelitian pada kondisi yang berbeda dengan penelitian-penelitian sebelumnya yaitu air tanah yang digunakan untuk irigasi di daerah yang dekat dengan pantai dan berpotensi terintrusi air laut.

Air irigasi di lokasi penelitian berada dalam kategori batasan penggunaan rendah untuk irigasi sehingga tidak sesuai untuk diberikan pada tanaman yang sensitif terhadap garam. Dengan demikian, air irigasi tersebut dapat diperuntukkan bagi tanaman-tanaman yang cukup sensitif terhadap garam, cukup toleran terhadap garam, serta toleran terhadap garam (Ayers \& Westcot, 1994). Kategori tanaman cukup sensitif, cukup toleran, dan toleran terhadap garam (Ayers \& Westcot, 1994) yang dapat disesuaikan dengan kriteria tanaman pertanian non-padi bernilai ekonomi tinggi (Haryono et al., 2009), dan telah umum diusahakan di wilayah Kabupaten Tuban (Badan Pusat Statistik Kabupaten Tuban, 2018), meliputi: jagung (Zea mays), kedelai (Glycine max), kacang tanah (Arachis hypogaea), ubi jalar (Ipomoea batatas), tomat (Lycopersicon lycopersicum), terong (Solanum melongena), mentimun (Cucumis sativus), bayam (Spinacia oleracea), melon (Cucumis melo), dan semangka (Citrullus lanatus). Kedelai (Glycine max) merupakan jenis tanaman yang cukup toleran terhadap garam, sedangkan tanaman-tanaman lainnya tersebut di atas merupakan jenis tanaman yang cukup sensitif terhadap garam. Jenis-jenis tanaman dengan kategori toleran terhadap garam (Ayers \& Westcot, 1994) tidak ada yang dapat disesuaikan dengan jenis-jenis tanaman pertanian yang sudah umum dibudidayakan di lokasi penelitian (Badan Pusat Statistik Kabupaten Tuban, 2018). Alternatif jenis tanaman pertanian non padi dengan nilai ekonomi yang tinggi dan dapat dibudidayakan pada lahan pertanian tersebut di atas dapat dilakukan di musim kemarau (saat tidak terjadi hujan) dimana sumber air irigasinya terbatas hanya berasal dari mata air karst.

Penentuan jenis tanaman pertanian non padi bernilai ekonomi tinggi yang dapat dibudidayakan di lokasi penelitian sebagaimana disebutkan di atas dilakukan berdasarkan kualitas air irigasi dengan kategori batasan penggunaan rendah. Alternatif jenis tanaman yang direkomendasikan dalam penelitian ini berbeda dengan alternatif jenis tanaman yang direkomendasikan dalam dua penelitian sebelumnya (Siswoyo et al., 2016; Siswoyo et al., 2020) untuk kategori kualitas air irigasi yang sama yaitu dengan batasan penggunaan air rendah. Faktor yang menentukan perbedaan dalam pemilihan alternatif jenis tanaman antara daerah yang satu dengan daerah yang lain adalah jenis tanaman yang cara bercocok tanamnya telah dikuasai oleh petani dan telah umum dibudidayakan di wilayah setempat. Dengan demikian, dapat dinyatakan bahwa metode penentuan alternatif jenis tanaman pertanian non padi bernilai ekonomi tinggi yang digunakan di dalam penelitian ini dapat digunakan secara umum dengan tetap memperhatikan kesesuaiannya terhadap kebiasaan petani dalam membudidayakan tanaman pertanian di tiap-tiap daerah. 


\section{KESIMPULAN DAN SARAN \\ Kesimpulan}

Pemberian air irigasi dari mata air karst di lokasi penelitian dapat dilakukan terhadap tanaman yang cukup sensitif, cukup toleran, dan toleran terhadap garam. Alternatif jenis tanaman pertanian non padi bernilai ekonomi tinggi yang dapat dibudidayakan di lokasi penelitian sesuai dengan kualitas air irigasinya antara lain: jagung (Zea mays), kedelai (Glycine max), kacang tanah (Arachis hypogaea), ubi jalar (Ipomoea batatas), tomat (Lycopersicon lycopersicum), terong (Solanum melongena), mentimun (Cucumis sativus), bayam (Spinacia oleracea), melon (Cucumis melo), dan semangka (Citrullus lanatus). Metode penentuan alternatif jenis tanaman pertanian non padi bernilai ekonomi tinggi berdasarkan kualitas air irigasi yang digunakan di dalam penelitian ini dapat diaplikasikan di lokasi lainnya dengan memberlakukan penyesuaian terhadap jenis tanaman yang kultur teknis atau cara bercocok tanamnya telah dikuasai oleh petani di daerah tersebut.

\section{Saran}

Petani yang memiliki lahan pertanian pada lokasi penelitian dapat memilih alternatif tanaman pertanian non padi bernilai ekonomi tinggi yang direkomendasikan berdasarkan hasil penelitian ini untuk diusahakan pada lahan pertaniannya. Alternatif jenis tanaman tersebut dapat diusahakan di musim kemarau dimana sumber air irigasinya hanya berasal dari mata air karst dan tidak terjadi hujan. Penelitian sejenis perlu dilakukan lebih lanjut untuk daerah-daerah dimana air tanahnya memiliki tingkat salinitas yang tinggi atau berpotensi terintrusi air laut.

\section{UCAPAN TERIMA KASIH}

Terima kasih kepada Fakultas Teknik Universitas Brawijaya yang telah membiayai kegiatan penelitian ini melalui Sumber Dana Penerimaan Negara Bukan Pajak berdasarkan Surat Perjanjian Pelaksanaan Kegiatan Penelitian No.: 06/UN10.F07/PN/2019. Artikel ini merupakan naskah publikasi bagian kedua (Publikasi II) dari kegiatan penelitian yang telah dilakukan.

\section{DAFTAR PUSTAKA}

Abdulhady, Y., Zaghlool, E., \& Gedamy, Y. (2018). Assesment of the Groundwater Quality of the Quaternery Aquifer in Reclaimedareas at the Northwestern El-Minya Governorate Egypt, using the Water Quality Index. International Journal of Recent Scientific Research, 9(1), 23033-23047. http://dx.doi.org/10.24327/ijrsr.2018.0901.1 385

Al-Mussawi, W. H. (2014). Assesment of Groundwater Quality in UMM ER Radhuma Aquifer (Iraqi Western Desert) by Integration between Irrigation Water Quality Index and GIS. Journal of Babylon University/ Engineering Sciences, 22(1), 201217.

Ayers, R. S. \& Westcot, D. W. (1994). Water quality for agriculture, FAO Irrigation and Drainage Paper 29 Rev.1. Rome: Food and Agriculture Organization of the United Nations.

Badan Pusat Statistik Kabupaten Tuban. (2018). Kabupaten Tuban Dalam Angka 2018. Tuban: Badan Pusat Statistik Kabupaten Tuban.

Djaenudin, D., Marwan, H., Subagyo, H., \& Mulyani, A. (1997). Kriteria Kesesuaian Lahan Untuk Komoditas Pertanian. Bogor: Pusat Penelitian Tanah dan Agroklimat Badan Penelitian dan Pengembangan Pertanian Departemen Pertanian.

Djaenudin, D., Sulaeman, Y., \& Abdurachman, A. (2002). Pendekatan Pewilayahan Komoditas Pertanian Menurut Pedo-Agroklimat di Kawasan Indonesia Timur. Jurnal Litbang Pertanian, 21(1), 1-10.

Haryono, E., Santoso, D., Sumarni, H., \& Indrakusuma, H. I. (2009). Kriteria Pengembangan dan Pengelolaan Irigasi Air Tanah. Jakarta: Direktorat Irigasi, Direktorat Jenderal Sumber Daya Air, Kementerian Pekerjaan Umum.

Hidayat, A., Suprayogi, S., \& Cahyadi, A. (2016). Penaksiran Kesesuaian Mataair untuk Irigasi 
di Kawasan Karst Sistem Goa Pindul. Dalam Suprayogi, S., Purnama, Ig. L. S., Cahyadi, A., \& Fatchurohman, H. (Ed.), Hidrologi dan Kepariwisataan Kawasan Karst Goa Pindul Kabupaten Gunungkidul (pp. 35-47). Yogyakarta: Badan Penerbit Fakultas Geografi (BPFG) Universitas Gadjah Mada.

Las, I. (1992). Pewilayahan Komoditi Pertanian Berdasarkan Model Iklim Kabupaten Sikka dan Kabupaten Ende, Nusa Tenggara Timur (Disertasi tidak dipublikasikan). Bogor: Institut Pertanian Bogor.

Khalaf, R. M. \& Hassan, W. Q. (2013). Evaluation of Irrigation Water Quality Index (IWQI) for Al-Dammam Confined Aquifer in the West and Southwest of Karbala City, Iraq. International Journal of Civil Engineering, 2(3), 21-34.

Lesch, S. M. \& Suarez, D. L. (2009). Technical Note: A Short Note on Calculating the Adjusted SAR Index. Transactions of the ASABE, 52(2), 493-496.

Meireles, A. C. M., de Andrade, E. M., Chaves, L. C. G., Frischkorn, H., \& Crisostomo, L. A. (2010). A New Proposal of the Classification of Irrigation Water. Revista Ciência Agronômica, 41(3), 349-357.

Omran, E. S. E., Ghallab, A., Selmy, S., \& Gad, A. A. (2014). Evaluation and Mapping Water Wells Suitability for Irrigation Using GIS in Darb ElArbaein, South Western Desert, Egypt.
International Journal of Water Resources and Arid Environments, 3(1), 63-76.

Saidi, B. B. \& Suryani, E. (2019). Pewilayahan Komoditas Pertanian Berdasarkan Zona Agroekologi Skala 1: 50.000 di Kabupaten Batanghari Jambi. Jurnal Ilmiah Ilmu Terapan Universitas Jambi, 3(2), 100-112. https://doi.org/10.22437/jiituj.v3i2.8192

Siswoyo, H., Agung, I G. A. M. S., Swantara, I M. D., \& Sumiyati. (2016). Determination of Groundwater Quality Index for irrigation and its Suitability for Agricultural Crops in Jombang Regency, East Java, Indonesia. International Journal of Agronomy and Agricultural Research, 9(5), 62-67.

Siswoyo, H., Bisri, M., Taufiq, M., \& Pranantya, V. (2019). Karakteristik Hidrokimia Mata Air Karst untuk Irigasi di Kabupaten Tuban. Jurnal IPTEK, 23(2), 93-100. https://doi.org/10.31284/j.iptek.2019.v23i2. 546

Siswoyo, H., Juwono, P. T., \& Taufiq, M. (2020). Model Indeks Kualitas Air Tanah sebagai Dasar Penentuan Alternatif Jenis Tanaman Pertanian pada Lahan Irigasi Air Tanah di Kabupaten Mojokerto. Jurnal Wilayah dan Lingkungan, 8(1). https://doi.org/10.14710/jwl.8.1.\%p

Zaenuri, M. A. \& Haryono, E. (2015). Diferensiasi Morfologi Karst Kabupaten Tuban-Jawa Timur. Jurnal Bumi Indonesia, 4(1), 1-10. 